\title{
Obituary
}

Editor: Henry R. Rollin

\section{Cicely Lamorna Hingston, MBE (Military), formerly Honorary Consultant Psychiatrist, The Royal Sussex County Hospital}

The death of Dr C. Lamorna Hingston in January at the age of 94 brings to an end a most remarkable career.

Dr Hingston was born on 26 August 1894, the daughter of a doctor. She was educated at Cheltenham Ladies College.

During the First World War she joined the VAD and was seconded to the WMAAC. She was posted to France where she served for no less than $4 \frac{1}{2}$ years and was awarded the MBE (Military), an exceptional decoration for a woman.

After demobilisation she became resident secretary at the Lady Chichester Hospital, Hove, Sussex to Dr Helen Boyle, a distinguished psychiatrist and the first woman president in 1939 of the Royal Medico-Psychological Association.

Undoubtedly inspired by Helen Boyle, Dr Hingston decided to study medicine and qualified MRCS, LRCP from St Mary's Hospital, Paddington in 1930. She worked for a time in general practice before specialising in psychiatry. For a time she worked as a clinical assistant at the Maudsley and took the DPM in 1933. She was elected a Foundation Fellow of the College in 1971.

In 1937 she followed in Dr Boyle's footsteps and was appointed visiting consultant to the Lady Chichester Hospital and also the Royal Sussex County Hospital, the Royal Alexandra Hospital for Children, and in 1938, to Southlands Hospital, Shoreham. As an exhibition of her special interest in the emotional disturbance in children, she was responsible for founding the Child Guidance Clinic at the Lady Chichester Hospital, the first such clinic in Sussex, and, further, in her appointment in 1942 to the staff of the East Sussex Child Guidance clinics at Hove and Lewes.

With the establishment of the NHS in 1948 she was appointed a consultant and as such she served the various hospitals in which she had previously worked on a voluntary basis.

When she had reached the age limit, in 1959, she retired from the NHS, although she continued to work in private practice. In 1949 she founded the Brighton and Hove branch of the League of the Hard of Hearing over which she presided for many years.
Dr Hingston was tireless in her service to the community as witness her membership of a number of hospital management committees, and her active interest in the local branch of the BMA, in addition to which she gave assistance to lay organisations including the Board of Governors of the Hove County Grammar School for Girls of which she became president.

\section{Mr Andrew Hibbert-Hingston, nephew, writes:}

If I may add a personal note, she was a devoted daughter, sister, and aunt, great- and great-greataunt, who took deep delight in her family. This did not prevent her from being noted for her humorous or astringent comments; she would puncture pomposity at once, though never unkindly. She was always interested in other people and all generations talked to her naturally and profited from the contact with so understanding a person. Actual advice was never volunteered without being asked for-but practical help often was, in many ways.

It is plain from the sheer number of bodies on which she served for so long, that her wisdom and humanity were out of the ordinary, and in great demand. A devout Christian all her life, she exemplified the ideal of service to others without ever a hint of becoming even remotely priggish.

\section{JAMES JOSEPH O'ReILLY formerly Medical Superintendent, All Saints' Hospital, Birmingham}

Dr J. J. O'Reilly, for many years the leading psychiatrist in Birmingham, died at the age of 90 in Northern Ireland in November 1988.

He was born on 5 April 1898 in Belfast, the son of a linen merchant. He received his education at $\mathrm{St}$ Patrick's College, Cavan, and at Queen's University, Belfast. Following posts as Assistant Medical Officer, at Somerset Mental Hospital, Wells, and Dorset Mental Hospital, he served as pathologist at the Hampshire Mental Hospital, Park Prewitt from 1928-1932. He then moved to All Saints' Hospital, Birmingham, where he was Medical Superintendent from 1938 until 1963. During this time he dominated the hospital and Midlands psychiatry, pioneering changes and developments in many areas as the National Health Service became established, and the 